\title{
Australian universities, generic skills and lifelong learning
}

\section{Tim Pitman \& Susan Broomhall}

To cite this article: Tim Pitman \& Susan Broomhall (2009) Australian universities, generic skills and lifelong learning, International Journal of Lifelong Education, 28:4, 439-458, DOI: $10.1080 / 02601370903031280$

To link to this article: https://doi.org/10.1080/02601370903031280

曲 Published online: 17 Aug 2009.

Submit your article to this journal $\asymp$

Џll Article views: 1028

Q View related articles $\asymp$

Citing articles: 22 View citing articles 


\title{
Australian universities, generic skills and lifelong learning
}

\author{
TIM PITMAN and SUSAN BROOMHALL \\ The University of Western Australia, Australia
}

The concept of lifelong learning implies a cycle where the learner contributes prior learning into a new learning environment and sees that learning upgraded. In recent years, a range of internal and external pressures have encouraged Australian universities to identify the meta or generic skills embedded in tertiary study. Using a content analysis of relevant university policy documents, this study assesses how the Australian higher education sector has presented this discussion through the notion of 'graduate attributes' and then analyses the implications of this conceptual transition. This article argues that the shift from a notion of generic skills to graduate attributes both reinforces and encourages universities to concentrate their participation in lifelong learning at one particular end of the cycle. This study suggests that, whilst informal experience is increasingly incorporated into university admission processes and even into credit for courses, progression towards a more equitable and accessible higher education sector remains patchy at best.

\section{Introduction}

In recent times there has been increased pressure by educational stakeholders, such as state and federal government and the wider business community, to ensure that Australian tertiary graduates are equipped not only with the skills and attributes specific to their course of study, but also with a suite of general, 'meta' skills suitable for the twenty-first century. These competencies, also known as generic skills or graduate attributes, include proficiency in communication, interpersonal skills, high-order reasoning, critical thinking and the ability to use technology. Australian universities have responded by producing statements about graduate attributes which, they argue, will enable and encourage students to 'continue learning throughout their lives, not only in the formal contexts mentioned above, but at home, at work, and in the community' (Candy et al. 1994: 32). Through the concept of graduate attributes, universities have positioned

\footnotetext{
Tim Pitman researches experiential learning, generic skills and lifelong learning at The University of Western Australia. He is currently an investigator for an Australian Learning and Teaching Council research grant exploring the pedagogical intersections between academia and educational tourism. Correspondence: Email: tim.pitman@uwa.edu.au.

Susan Broomhall researches educational tourism, experiential and lifelong learning in the School of Humanities, The University of Western Australia. She is currently an investigator (with Pitman) in an Australian Learning and Teaching Council research grant exploring the pedagogical intersections between academia and educational tourism. She is also chief investigator on an Australian Research Council Linkage grant analysing ontologies of place in educational and cultural tourism in Australia. Correspondence: broomhal@cyllene.uwa.edu.au
} 
themselves as key players in the development of a culture of lifelong learning in their graduates and-by extension-the broader community. However, are the 'graduate attributes' of universities the same concept as 'generic skills'? What are the implications for how the tertiary sector recognizes and develops lifelong learning skills? In this article, university policy documents are assessed through a content analysis to examine precisely how and why universities have conceptualized their participation in the lifelong learning cycle in the current political and economic context of the Australian tertiary sector.

\section{The advent of lifelong learning agendas in the Australian higher education sector}

The term 'lifelong learning' has become so much a part of the lexicon of higher education language worldwide that it has, as educational psychologist Christopher Knapper (2001: 130) suggested, become a 'ubiquitous slogan that appears in government position papers, university mission statements and advertising literature for all manner of educational products and services'. Many external stakeholders-most notably politicians and government agencies-see the primary aim of lifelong learning as maximizing the economical benefits that flow from the development of such skills (see European Ministers of Education 1999, OECD 2003). In Australia, a set of generic skills, the 'Mayer Key Competencies' (MKC), were identified by the federal government in 1992 in response to a call from the business community for the post-compulsory education sector to produce graduates with contemporary, assessable and functional skills needed for the immediate and longterm economic benefit of the country. The new 'adaptable and flexible' worker was said to need, in addition to specific skills, a set of generic skills transferable across changing work sites and different occupations (Williams 2005: 35).

Social agendas, by contrast, tend to be more prominent in university lexicons with the sector as a whole typically highlighting the social capital accruing from their actions. Most institutional texts contextualize the purpose of lifelong learning in their institutions as a means of meeting the educational needs of an ever more diverse group of learners (Schuetze et al. 2002) by, for example, placing a focus on all learning experiences that Knapper and Cropley (2001) define as being intentional and goaldirected, and not just those seen as having 'traditional value'. University statements do not however ignore the economic value of lifelong learning, just as governments and others additionally promote social goals in any lifelong learning policy. Indeed, this symbiotic relationship between social and economic agendas has been noted in recent research. For example, in a study of refugees and asylum seekers experiencing disenfranchisement in the UK, Morrice (2007) highlighted the potential of these immigrants to use lifelong learning to both access educational opportunities and have their skills and experience utilized economically, to the benefit their host nation.

In Australia, the push to articulate generic skills has been strongly influenced by federal government educational policies of the past decade, which have attempted increasingly to tie funding to performance through a series of accountability measures. Unlike those in the US and UK, Australian universities have only recently been subject to any form of external quality assessment. ${ }^{1}$ The Australian Universities Quality Agency (AUQA) was formed in 2001 with no foundation of prior attempts at external quality assurance (James 2003: 189). In the same year, the Australian 
Council for Educational Research (ACER) was commissioned by the federal Department of Education, Training and Youth Affairs (DETYA) to identify a set of generic skills which could be effectively assessed at university entry and exit level (ACER 2001). Universities have thus increasingly found themselves pressured to equip their graduates with 'marketable knowledge' (Jongbloed 2002: 416) and to harness the lifelong learning potential to improve health, reduce criminal activity and engage more positively with communities-all via the attainment of higher educational outcomes arising from a strong lifelong learning policy (Watson 2003: 27).

It is unsurprising therefore that the higher education sector has increasingly sought to demonstrate a range of benefits delivered to students from their institution that will position them as important players in any holistic lifelong learning agenda. This has been particularly important as, over the same period, the federal government has produced mixed messages about its valuation of, and support for, the product of the higher education sector. In 2003, the then minister of education and training, Dr Brendan Nelson, announced his view that many universities were 'bleeding' resources away from traditional, high quality courses towards popular options such as 'paranormal, golf course management, surf board riding and aromatherapy' (Nelson 2003). A focus on generic skills is one way in which universities can counter this criticism, as it speaks of a liberal arts tradition and enabled them to articulate an edge over other, more technical, knowledge and skill providers, such as the vocational education and training (VET) sector with whom they compete for resources, such as government funding, student market and community prestige. ${ }^{2}$ This demonstration of the sector's engagement with lifelong learning has been achieved primarily through the identification and promotion of a series of general skills that are common to more than one work site, more than one occupation or more than one field of knowledge (Golding et al. 1996). University documents now accept the notion that workers with a suite of such general, or transferable skills, will be better placed to survive and succeed in a globalized knowledge economy (Chapman et al. 2005: 110) and argue that they assist by equipping their graduates with the appropriate skills, regardless of the discipline they are studying. These are typically termed 'graduate attributes'.

That university staff believe in their ability to increase students' capacity to learn, to provide them with analytic skills and to increase their ability to deal with new information and draw independent conclusions is not a modern concept, of course (Gow and Kembler 1990). Philip Candy (1994: iv) cited Cardinal Wooley's opening address in 1862 at Australia's oldest university, the University of Sydney, as evidence that universities had always claimed various sets of generic attributes for their graduates:

Our undergraduates will, we may reasonably hope possess a well-cultivated and vigorous understanding: they will have formed the habit of thinking at once with modesty and independence; they will not be in danger of mistaking one branch of science for the whole circle of knowledge, nor unduly exaggerating the importance of those studies they select as their own. Above all they will have attained the truest and most useful result of human knowledge the consciousness and confession of their comparative ignorance. (Candy 1994: iv)

However, in recent years, there has been significant external pressure for specific generic skills to be identified, valued and explicated. In Australia, the desired 
generic skills, or 'key competencies', were initially elaborated in two major reports, the 1991 Finn committee's report, 'Young people's participation in post-compulsory education and training' and the 1992 Mayer committee's report, 'Putting general education to work: the key competencies report' (Williams 2005: 36). Having defined the key competency areas, the Finn committee recommended that the next step should be the development of a standards framework for each of the key competencies with a 'profile' which described clearly the nature of each competency at a range of levels. This was the task of the Mayer report, which identified seven competencies:

(1) Collecting, analysing and organizing information.

(2) Communicating ideas and information.

(3) Planning and organizing activities.

(4) Working with others in teams.

(5) Solving problems.

(6) Using mathematical ideas and techniques.

(7) Using technology.

Against recommendations from both industry and community groups, the Mayer committee excluded more subjective concepts such as individual values or attitudes (Williams 2005: 36). Similarly, the identification of generic skills in the 2001 ACER study, which had consulted with universities and other interested parties, was complicated (perhaps compromised?) by the need to distinguish skills that were considered vital but also assessable. Indeed, of the skills recommended, written communication, critical thinking, problem solving and interpersonal understandings were justified in the report for inclusion in the initial test because they were 'popular' with universities, seemed to be essential elements of other skills (such as capacity for lifelong learning) and were likely to be transferable and readily measurable (ACER 2001: 1). A 2003 international analysis of skills sought by businesses employing graduates and encompassing countries in Europe, and across the Commonwealth (including Australia, Asia and the subcontinent) and North America, similarly found that communication emerged as the most important skill valued by stakeholders. The other skills rated highly were teamwork, self-management, problem-solving, conceptual skills and social interaction (interpersonal) skills (Billing 2003). As with other studies (ACER 2001, Hambur et al. 2002), Billing observed that employers viewed the issue of transferability as unproblematic-in other words the possession of generic skills was ipso facto indicative of an ability to transfer them from one context to another. The conceptualization of specific skills has proved by no means straightforward.

Driven by economic pressures to attend to government and industry's identification of 'appropriate' generic skills and their own support for social lifelong learning agendas, universities have acted to establish themselves as an integral component of the lifelong learning cycle, via the facilitation of such skills. One of the first and most effective actions in this respect has been to redefine these skill-sets as 'graduate attributes'. The use of this phrase clearly situates the development of such skills within a formal tertiary educational setting: the implication being that such skills cannot be developed elsewhere. In an examination of the application of recognition of prior learning (RPL) in Australian universities, Louise Wheelahan used this notion of 'graduateness' to pinpoint the belief by many within the sector that graduate 
attributes were superior and unique identifiers of a student with a university education and that could not be obtained from outside the tertiary institution:

Sometimes when a student was granted RPL for a whole qualification or for a substantial part of a qualification, [they] lacked something that other graduates had. Sometimes this was explicit, for example, students were said not to have the same literacy skills as other students. Other times it was more diffuse and was explained in terms of "the sum being greater than the parts. (Wheelahan 2003: 3-4)

Universities have thus selected a terminology to express their engagement with lifelong learning that positions them as unique providers of a particular set of generic skills. The concept of 'graduate attributes' would seem a logical organizational response to a perception of operating in an increasingly competitive funding environment and a public (and related) devaluing of the university education relative to other post-secondary options.

In order to fully control this required skills set, universities have had to develop tasks to enable learners to practice and then reflect on their progress (Luca and Oliver 2003). Some actions have been primarily symbolic, or strategic, such as the revision of institutional goals or missions to adopt broader and alternative notions of knowledge and wisdom (Barrie 2004: 268). Other (usually concurrent) actions could be considered tactical: for example, many universities have identified the need for, and developed, learning settings that focus on process, student-centred activities and experimentation rather than subject content (Candy et al. 1994, Luca and Oliver 2003). These responses consider graduate attributes as important university learning outcomes that allow students to make use of and apply discipline knowledge.

Thus, the recent articulation of a clear suite of generic skills to be found in university graduates is a rational response to the range of recent pressures to justify taxpayer and industry investments and emphasize the importance of higher education institutions in lifelong learning. The specific choice of the term 'graduate attributes' moreover represents an attempt by the higher education to position itself as a provider of unique skill sets not to be developed in other post-secondary educational settings. However, the adoption of the concept 'graduate attributes' to define universities' participation in lifelong learning has also had other implications for how the higher education sector interacts with the broader lifelong learning cycle. These will be explored in the section to follow.

\section{Reconceptualizing generic skills as graduate attributes}

At first glance, any difference between 'generic skills' and 'graduate attributes' may appear largely pedantic as they appear to be different phrases for essentially the same concept. Billing (2003: 335) quotes the UK Higher Education Quality Council (HEQC) as identifying generic skills as a mark of 'what makes a graduate', thus reinforcing the link between the two terms. Barrie (2004: 262) states that the two terms are often used interchangeably or are even hybridized to 'generic attributes'. Similarly, when Philip Candy was commissioned by the Australian Higher Education Council $(\mathrm{HEC})^{3}$ to identify and describe the characteristics of undergraduate 
education which facilitated lifelong learning, he chose to label these as 'generic' or 'transferable' attributes (Candy 1994: 61). It appears, to date, that the two terms have been used with relatively little consideration of distinctions between the kinds of learning that they imply conceptually or delineate in practice.

However a closer examination reveals that, within the sector's own policy documentation, the term 'graduate attributes' is preferred and seems to signify its attempt to pursue a different vision of the lifelong learning agenda than that encapsulated in government and industry's term 'generic skills'. To investigate this in detail, this study searched each of the 38 Australian universities' websites for evidence of a formal statement of graduate attributes. This involved a content analysis of fora in which discussions of lifelong learning were likely to occur: typically mission statements, teaching and learning guidelines and advice to prospective students. The data were expressed in publicly-available documentation in generic formats such as written policies, statutes, rules, protocols and handbook text. In selecting such data, we are seeking to identify sector-wide trends, but we recognize that universities are large, multi-functional organizations in which many parts produce documentation designed for engagement with different groups. The documents from one university are unlikely to exhibit a single, institutional-level vision of lifelong learning: indeed, there may be more similarities in texts developed within a certain segment of universities across Australia who share a common function. A variety of statements about lifelong learning within the sector and its individual institutions may not necessarily indicate confusion among its parts, for an apparent lack of organizational co-ordination or rationality could be both a productive and even deliberate positioning (Brunsson 1985, 1989, Meyer and Rowan 1991). Some organizational sections are charged with functions that interact with external stakeholders (whether they are government departments, welfare groups, or prospective students), who themselves represent diverse interests. In other cases, some areas of the institutions may be promoting ideologies that are not neatly aligned with those of others: equity access agendas may not always sit well with those responsible for increasing revenue into the institution. In some cases, the teaching departments of an institution may produce texts that reflect a temporal or cultural delay to messages that can be found emanating from the executive level of the organization. These differences in organizational function and processes of change will inevitably mean that there are inconsistencies in lifelong learning conceptualizations across the varied organizational segments that produce the documentation used in this analysis.

There are university documents that now refer to, and discuss the importance of, graduate attributes almost universally across the sector (37 out of 38 institutions). Moreover, 34 universities provide detailed information specifying what these attributes are, in the form of formal university policy, teaching and learning guidelines and procedures for curriculum development. In total, 25 distinct attributes have been identified in Australian university statements: more than tripling the number of government-recommended competencies derived from the MKC. The attributes, and the frequency with which they appear in university lists, are shown in Table 1.

Some of these skills replicate those to be found in the MKC list. Although no single attribute is common to all university sets of attributes, communication skills comes extremely close, cited in 33 out of 34 Australian university statements. The next two most highly-rated attributes-interpersonal skills and problem solving-also relate 
Table 1. University graduate attributes and associated Mayer Key Competencies

\begin{tabular}{|c|c|c|}
\hline Graduate Attribute & $\begin{array}{l}\text { Corresponding Mayer } \\
\text { Competency }\end{array}$ & $\begin{array}{l}\text { Number of } \\
\text { universities } \\
\text { articulating this } \\
\text { attribute }(n=34)^{1}\end{array}$ \\
\hline Communication skills & $\begin{array}{l}\text { Communicating ideas and } \\
\text { information }\end{array}$ & $33(97 \%)$ \\
\hline Interpersonal skills & Working with others in teams & $28(82 \%)$ \\
\hline Problem-solving skills & Solving problems & $24(71 \%)$ \\
\hline $\begin{array}{l}\text { Master of specific (i.e. disciplinary) } \\
\text { knowledge }\end{array}$ & $\mathrm{n} / \mathrm{a}$ & $24(71 \%)$ \\
\hline $\begin{array}{l}\text { Awareness and respect for others } \\
\text { (including cultural awareness, national } \\
\text { and international perspective) }\end{array}$ & $\mathrm{n} / \mathrm{a}$ & $24(71 \%)$ \\
\hline Critical/analytical thinking & $\mathrm{n} / \mathrm{a}$ & $23(68 \%)$ \\
\hline Behaving ethically & $\mathrm{n} / \mathrm{a}$ & $22(65 \%)$ \\
\hline Lifelong learning & $\mathrm{n} / \mathrm{a}$ & $21(62 \%)$ \\
\hline Creative thinking & $\mathrm{n} / \mathrm{a}$ & $17(50 \%)$ \\
\hline $\begin{array}{l}\text { Professional skills (including ability to } \\
\text { apply disciplinary knowledge in the } \\
\text { workplace, plus more generic skills such } \\
\text { as time management, working } \\
\text { autonomously) }\end{array}$ & $\begin{array}{l}\text { Planning and organizing } \\
\text { activities }\end{array}$ & $17(50 \%)$ \\
\hline $\begin{array}{l}\text { Leadership and/or service in the local } \\
\text { and wider community }\end{array}$ & $\mathrm{n} / \mathrm{a}$ & $16(47 \%)$ \\
\hline Information literacy & $\begin{array}{l}\text { Collecting, analyzing and } \\
\text { organizing information }\end{array}$ & $14(41 \%)$ \\
\hline $\begin{array}{l}\text { Technology literacy (esp. information } \\
\text { technology) }\end{array}$ & Using technology & $13(38 \%)$ \\
\hline $\begin{array}{l}\text { Reflective thinking (aka self- } \\
\text { development or independent thinking) }\end{array}$ & $\mathrm{n} / \mathrm{a}$ & $11(32 \%)$ \\
\hline Adaptability to change & $\mathrm{n} / \mathrm{a}$ & $8(24 \%)$ \\
\hline Open-mindedness & $\mathrm{n} / \mathrm{a}$ & $6(18 \%)$ \\
\hline Environmental awareness & $\mathrm{n} / \mathrm{a}$ & $6(18 \%)$ \\
\hline $\begin{array}{l}\text { Numeracy skills (aka information } \\
\text { numeracy) }\end{array}$ & $\begin{array}{l}\text { Using mathematical ideas } \\
\text { and techniques }\end{array}$ & $5(15 \%)$ \\
\hline Agent for change (aka enterprise skills) & $\mathrm{n} / \mathrm{a}$ & $5(15 \%)$ \\
\hline Self-confidence & $\mathrm{n} / \mathrm{a}$ & $5(15 \%)$ \\
\hline $\begin{array}{l}\text { Awareness of and sensitivity to } \\
\text { Indigenous culture }^{2}\end{array}$ & $\mathrm{n} / \mathrm{a}$ & $3(9 \%)$ \\
\hline Enthusiasm & $\mathrm{n} / \mathrm{a}$ & $2(6 \%)$ \\
\hline Research skills $^{3}$ & $\mathrm{n} / \mathrm{a}$ & $2(6 \%)$ \\
\hline Search for truth & $\mathrm{n} / \mathrm{a}$ & $1(3 \%)$ \\
\hline Mentor to future generations of learners & $\mathrm{n} / \mathrm{a}$ & $1(3 \%)$ \\
\hline
\end{tabular}

${ }^{1}$ The value in brackets indicates the percentage of policies in which this attribute appears

${ }^{2}$ Where this was listed in addition to a more general awareness of other (e.g. international) cultures

${ }^{3}$ Where this was listed in addition to the more general construct of 'information literacy' 
to specific MKC. However in other respects, a comparison of university graduate attributes to the MKC lists illuminates some significant differences. For example, numeracy skills are listed in only five institutional texts as an attribute inherent in all of its graduates. Numeracy is cited as often as 'self-confidence' and acting as 'agents for change' and less often than, for example, 'open-mindedness' or 'leadership in the community'. Thus, a key generic skill as rated by Mayer and indeed in much other research into educational stakeholder needs (Billing 2003, Chapman et al. 2005) appears to be downplayed as a guaranteed outcome of the majority of higher education studies in Australia.

Significantly, many institutional statements establish specific disciplinary knowledge as a key graduate attribute. It is listed as or more often than six of the seven generic competencies identified by Mayer. As many texts listed expert knowledge as important as the more generic ability to solve problems. The mastery of a corpus of specific disciplinary knowledge cannot in most instances be acquired outside of the higher education sector. In this case, the use of graduate attributes, rather than the terminology of generic skills, enables some documents, typically those institutions with a long liberal arts tradition (colloquially known in Australia as 'sandstone' or 'group of eight' universities), to highlight their core teaching function. It represents a significant reformulation of the supposed purpose to which defining specific generic skills responds, that the knowledge of whole disciplines can be reduced to an educational 'graduate attribute' or 'skill'.

Importantly, graduate attributes as defined by the higher education sector encompass a range of moral, ethical and character traits. The Mayer committee, by contrast, had explicitly excluded values and attitudes from the scope of its competencies (AEC Mayer committee 1992: 13). Yet these characteristics have long been recognized by government and the sector as one of three key skills sets which included basic skills, intellectual skills and personal attributes. 'Personal attributes are attitudes and abilities that enable individuals to monitor and manage their own learning needs, to contribute to and monitor their own work and to collaborate with others in high performance work teams' (Curtis and McKenzie 2001: 54). As a whole, more Australian university texts list abstract concepts, such as cultural awareness and ethical behaviour, than professional skills, information or technology literacy, or even numeracy. Ethical behaviour, for example, is commonly expressed as a value to be found in graduates. However some attributes can be articulated both as values and as skills. Cultural awareness is often proposed as a value or outlook that involves: 'An acknowledgment of and respect for equality of opportunity, individual and civic responsibility, other cultures and times, and an appreciation of cultural diversity' (Murdoch University).

However in other statements, it is also defined as a specific skill, as in: 'The ability, through your understanding and valuing of difference and diversity, to live and work in culturally diverse communities'. Indeed, some texts conceptualize this attribute as both a value and a skill, such as one that states graduates should 'respect the rights of others irrespective of their cultural background, race or gender' and also be able to 'function in a multi-cultural or global environment'. In this way concepts of good character and citizenship are intertwined with more pragmatic considerations of working in a framework of global employment. Likewise, lifelong learning is jointly expressed as a value ('a commitment to lifelong learning... as a quality to be fostered') and a skill ('Utilize lifelong learning skills'). 
Naturally, Australian institutions enjoy a different profile in the broader community and service different demographics. Table 2 groups the statements of generic skills by recognized university group in order to identify trends in the attributes emphasized that may be apparent between segments of the higher education sector. It examines the frequency with which the top 10 attributes across the sector appear within statements produced by the distinct sectoral groupings. There are four active collaborative groupings for the purpose of marketing and lobbying within the Australian tertiary sector: these are the Group of Eight (Go8); the Australian Technology Network (ATN); Innovative Research Universities Australia (IRU Australia) and the New Generation Universities (NGU). ${ }^{4}$ The remaining universities we have termed Unaligned Universities (UU). An analysis of the universities in this way demonstrates the pre-eminence of communication skills as a graduate attribute in all segments of the tertiary sector. Some attributes appear to occur in alignment with sectoral position. 'Behaving ethically' appears more frequently in statements with the Go8 universities where $86 \%$ of the statements include mention of this moral attribute of graduates, than in those of other segments $(50 \%, 67 \%, 56 \%$ and $63 \%$ respectively). The Go8 universities include Australia's oldest institutions, typically with strong liberal arts traditions. By contrast, the attribute of 'awareness and respect of others' was represented in $89 \%$ of the texts formulated within NGU (institutions that received university accreditation since 1970 and typically service diverse student populations, including relatively high proportions of mature-age and international students) compared to those of Go8 institutions (with relatively low student diversity and high school-leaver populations) where it featured in only $57 \%$. Overall, Table 2 demonstrates some distinctions within the sector although these are not always easily explained by the groupings in which they occur. Critical or analytical thinking, for example, ranges within the sector from appearance in $100 \%$ of IRU statements and $86 \%$ in Go8 texts, to $44 \%$ of those in NGUs. This suggests that, although the sector as a whole has taken a united approach to the re-definition of generic skills as graduate attributes, the correlation of these attributes to sectoral position within the market still indicates considerable institutional variance.

The more the phrases of 'generic skills' and 'graduate attributes' are unpacked in such a way, the more significant the differences become. 'Generic' (inclusive of many kinds of, and fora for, learning) is replaced by 'graduate' (excluding those not attending the specific institution). Universities have historically and regularly ignored or marginalized learning acquired outside of their curricula because of the challenge it presents to their claims to be the guardians of knowledge (Michelson 1996, Trowler 1996, Broomhall 2004). 'Graduate' situates the locus of instruction within the institutions' walls. It allows a 'personalization' of the skill set: generic is unspecific whereas a graduate is 'owned' by a sole institution, thus allowing the university materials to talk about 'us' and 'our' when referring to attributes such as interpersonal skills, literacy or numeracy. 'Skills' (definable and of particular economic advantage) are replaced by 'attributes' (abstract, with a broader social agenda). By shifting from skills to attributes, these texts re-contextualize the intellectual framework from a relatively narrow economic construct, to one that more fully embraces a moral and social agenda. A skill refers to the ability to do something well, such as a technique: it thus refers to a specific and usually economically exploitable type of expertise. This naturally evokes an environment of work, or training. By contrast an attribute, according to the Australian Oxford Dictionary, is a 'characteristic quality ascribed to a person or thing'[authors' emphasis]. Attributes speak of 


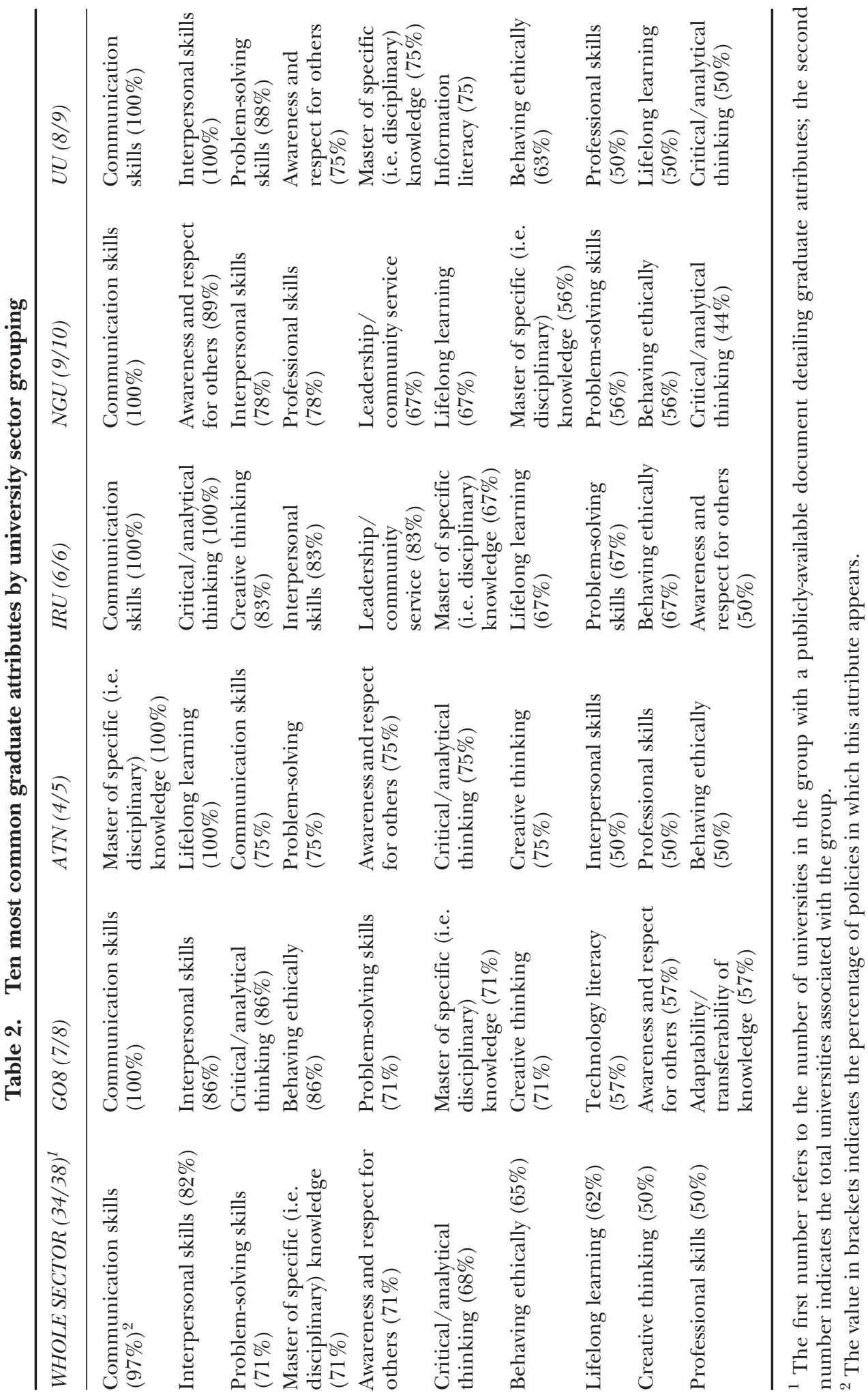


value, or moral worth. They are not constrained by measurable outcomes, such as the ability to land an aeroplane safely, or build a bridge that will not collapse. Rather, they draw on those elements invoked in 1862 by Cardinal Wooley: cultivation, modesty, independence and truth. Skills are banal; attributes by contrast have moral superiority.

One of the implications of the shift from generic skills as graduate attributes has been to shield (inadvertently or otherwise) the sector from direct scrutiny, most particularly in the form of empirical assessment. In 2000 the federal government, through the Department of Education, Science and Training (DEST) piloted the use of a 'Graduate Skills Assessment' (GSA) which was specifically designed to assess the generic skills of university graduates. The test was designed by the Australian Council for Educational Research (ACER) and tested similar skills to the MKC, namely:

- Critical thinking.

- Problem-solving.

- Interpersonal understanding.

- Written communication.

It was argued within the GSA documentation produced by DEST that:

At exit level the results could be used... by employers to assess generic skills for employment purposes. The GSA could also be used to measure the value added by institutions for cohorts who take the test at both entry and exit or to compare student profiles between fields of study. (http:// www.dest.gov.au)

Furthermore, the report claimed that skills testing provided an impartial measure of student performance that is not coloured by differences in academic standards in particular courses or institutions' (as cited in Clerehan et al. 2003).

Scholarly reaction to the GSA has been decidedly cool, perhaps not surprising in a professional culture for whom external quality assessment has been a recent intervention. Gosden and Hampton (2001) considered that students with learning disabilities would be disadvantaged. Clerehan argued that many of the skills listed in the GSA did not lend themselves to psychometric testing and that questions displayed cultural and linguistic biases which seemed likely to disadvantage students from a variety of backgrounds (Clerehan et al. 2003). Chanock (2004: 23) suggested that the GSA did not test the 'appropriate' skills and that universities might waste valuable time 'teaching their students how to pass the test'. The majority of universities do not support and therefore administer the GSA. As a result, its value and validity is undermined (ACER 2002). Because it is consequently an imperfect tool, universities have argued that they are unwilling to subscribe to it (Australian Vice Chancellors' Committee [AVCC] 2006).

As an alternative model to external validation, individual assessment has been proposed by the sector. In 2005 a project team from The University of Sydney developed a web resource for graduates-'Life Long Earning' (sic) — that placed the responsibility for assessing generic skills on the graduate, rather than an 'independent umpire' (Taylor et al. 2005). Noting the almost overwhelming antipathy to the GSA the researchers suggested that: 
... along with the skills of life long learning go the skills of life long self assessment ... as it is the employer that ultimately makes decisions about new employees, it is the individual who should be assessing his/her own development of skills. (Taylor et al. 2005: 565-566)

Such a proposition, which would avoid direct government accountability by arguing that self-assessment provides an opportunity for lifelong learning in practice, highlights how the sector has logically sought to engage with lifelong learning and its assessment in ways that protect its own values.

Coupled with the scholarly argumentation against the GSA then has been the sectoral response to re-conceptualize of skills as attributes that is evident in the documentation above. How exactly could one measure 'awareness and respect for others'-an attribute produced by as many universities as problem-solving skills? Can 'behaving ethically' - an attribute purportedly inculcated in almost two-thirds of Australia's graduates-be metricated? By pro-actively determining their own indicators of performance and shifting from concepts of employability and economic values to broader socio-economic ones, it becomes more difficult for the government to perform standardizing tests and quality audits upon the higher education sector. In this formulation, generic skills have transformed from a relatively universal, publicly-owned and measurable concept, to a personalized, unmeasurable asset. With this view, how then can universities participate in the lifelong learning cycle as accreditors of the lifelong leaning of others? In the next section, we explore whether there are generic skills developed elsewhere in the education sector that universities can afford to recognize.

\section{Recognizing generic skills: the missing link in higher education's lifelong learning cycle?}

In 1994, in the final report to the Higher Education Council on the development of lifelong learners through undergraduate education, Candy et al. noted that:

Universities... represent an important part of the temporal continuum extending from the cradle to the grave... [they must] be aware of, and responsive to, the past experiences, knowledge bases and aspirations of those coming from elsewhere in the educational spectrum. (Candy et al. 1994: 31-32)

This description posits lifelong learning both as a cycle and continuum, a process in which Australian universities have an important place. It is apparent that universities see it as their role to provide their students with 'graduate attributes' through the application of their academic programs. However this addresses only one direction of flow of the lifelong learning cycle; that is their contribution as providers of skills or attributes. When admitting a school-leaver into an undergraduate degree, the university recognizes-and exploits—-the learning students have acquired from primary, secondary and life experience. At the conclusion of the degree program (it is hoped), students will have learnt more and leave with greater skills than that with which they commenced; particularly generic skills or attributes. Should they, after a break, return to postgraduate studies, their previous output skills, plus any new 
learning acquired, could become their new input skills and so on. Does the sector therefore also contribute at the other end of the lifelong learning cycle, as accreditors of the generic skills or attributes of those seeking to enter universities?

The example of the graduate diploma provides an opportunity to examine the sector's practice regarding accreditation of generic skills as inputs to the higher education system. As in other countries, in Australian universities admission and academic personnel charged with assessing applicants for graduate diplomas presume that the student has acquired the necessary information literacy, communication and problem-solving skills in order to allow them to complete postgraduate studies in another discipline and in an accelerated time frame. It functions on the assumption that university education provides the student with sufficient output generic skills (graduate attributes) to enable them to succeed at a postgraduate level in an entirely unrelated field or discipline. Thus, within the Australian higher education sector, graduate attributes are perceived as invaluable entry criteria, even if the sector is unwilling to place a universally shared external measure on them.

By contrast, higher education's approach to input generic skills appears very different. This can be examined through the way in which universities indicate the value of input generic skills can be judged by the extent to which they recognize the prior learning experiences of prospective students for the purposes of admission and/or credit. More specifically, the recognition of prior informal or uncredentialed learning, also known as RPL, is a means whereby key university staff (e.g., admissions or academic) can acknowledge, assess and to a degree quantify the extent to which prospective students have acquired various skills-generic or otherwise-and recognize their contribution towards a higher education degree. RPL has been seen by both scholars and external stakeholders as one of the most significant ways that universities can advance a lifelong learning agenda (National Board of Employment, Education and Training [NBEET] 1990, Taylor and Clemans 2000, OECD 2001, Wheelehan et al. 2003). Yet there has been no economic incentive for universities to support this form of lifelong learning, because they are currently not allowed to charge students for RPL (Funding and Support Branch Higher Education Group 2006: 38).

Using the same research method adopted for the collection of graduate attribute data, a systematic content analysis was conducted of the 38 universities' policies concerning RPL. These are primarily produced in formal policy documents developed within both admission departments and committees related to teaching and learning agendas. The results showed a significant variance to those for graduate attributes. There is no economic advantage to prioritizing students entering with RPL. Even from a purely economic perspective therefore, it is not surprising perhaps that only 29 universities currently allow prospective students to exploit RPL. Only 24 institutions provided a written policy. Yet, as we have seen above, universities also promote the social and community contributions of their participation in lifelong learning agendas. In that respect, there is a contrast between the graduate attributes championed by all bar one institution as an aspect of lifelong learning and the RPL which is permitted at just over three-quarters of universities.

As with graduate attribute statements, the language used to describe RPL in relevant documents reveals much about the sectoral attitudes towards this form of generic input skills. Unlike output skills, RPL tends to be framed in tightly-defined, delineated ways. In order to receive any recognition for prior learning, applicants have to demonstrate that they can achieve the outcomes of a unit of study in precisely- 
defined terms. The following statement, in almost identical phrasing, is found in over half the policies: '[RPL] shall be granted only when the applicant can demonstrate equivalent skills and knowledge to that gained if the relevant [University] studies were undertaken'.

Since units of study are invariably phrased in terms of specific and multiple outcomes, it is extremely difficult for an applicant to gain credit for broad, general experience, even where that experience equipped him or her with tertiary-level literacy or numeracy skills. The difficulty for the applicant is exacerbated by the requirement from most universities that all competencies have to be demonstrated in order for recognition to occur, such as the statement that: 'Credit will not be granted for part of a subject'. Thus, even if applicants were able to demonstrate multiple generic input skills, such as problem-solving, interpersonal skills and information literacy, it could not be recognized if they could not also demonstrate complete understanding of the specific disciplinary knowledge for the unit of study. Just as the survey of graduate attributes showed that mastery of a specific discipline was considered an important graduate attribute for many universities, the analysis of prior learning policies shows that it is equally valuable to the sector as an input skill. These documents operate in such a way as to maintain universities' long-established claims to be the guardians of a superior form of knowledge, claims that have been acculturated in the sector through professional codes and norms (Bucher and Strauss 1961, Michelson 1996, Trowler 1996, Leicht and Fennell 1997, Broomhall 2004). Such evidence reflects the tensions within universities about their desire both to promote their role as facilitators for lifelong learning and the priority they seek to place on the primacy of specific disciplinary knowledge that only they can provide.

In addition, the language surrounding the evidence required of prior learning also indicates the sector's conceptual discrepancies in its approach to generic skills. The scholarly reaction to the GSA highlights concerns about external attempts to measure the generic skills universities produce (graduate attributes). However the RPL policies of Australian universities display the opposite position when it comes to assessing generic skills as a criterion of admission. Seventeen of the 26 RPL policies contain an explicit statement to the effect that prior learning was only valid if it could be demonstrated. In the remaining nine policies the requirement exists in implicit form, such as the university that states 'RPL assessment will be evidence and outcome-based'. The onus is on learners to provide empirical evidence that their generic skills exist. Thus, whereas graduate attributes are promoted in a spirit of 'can do', prior learning is a case of 'must prove'.

The Australian tertiary sector also measures generic input skills via the application of special or alternative admission tests. The most widely used generic skills assessment test in Australia is the Special Tertiary Admission Test (STAT) which has been developed by the Australian Council for Educational Research (ACER), the same organization that developed the much-criticized GSA. The STAT assesses core competencies deemed necessary for university entrance, and crucially tests critical thinking and reasoning skills, rather than institutionally-inculcated knowledge. A test such as the STAT thus would seem to offer a mechanism for universities to quantify at least four of the competencies identified by Mayer-namely: collecting, analysing and organizing information; communicating ideas and information; solving problems; and using mathematical ideas and techniques.

However, in practice, the application of such tests is limited in several significant ways. Firstly, university policies only permit them to be used to meet admission 
requirements: demonstration of appropriate generic competencies will not result in credit being approved. Secondly, not all universities accept the STAT-by far the most common alternative admission test-as a means of entry. Although 31 out of 38 universities accept the test, only two of these universally accept the STAT for admission to any and all of their academic programs (one NGU and one unaligned university). In the remaining 29 institutions, various conditions are placed upon the STAT, relating either to the types of persons who can use the STAT, or the courses that accept it as a basis of admission, or both.

Investigating these conditions further yields revealing information about the sector's understandings of lifelong learning. In cases where conditions are placed on the type of the applicant who can use the STAT, the majority of these university policies excluded applicants under the age of 20. An analysis of the available documents revealed no explicit justification for this restriction, however two hypotheses can be proposed. The first is that applicants under the age of 20 may not be considered to possess sufficient 'life experience' to justify using a generic skills test. We have not been able to identify any research that has tested such an assumption. The second hypothesis is that alternative admission tests are restricted to applicants with no prior, or recent, experience in post-compulsory education (i.e., Years 11 and 12, or the matriculation years in secondary schools) because students with that background might have an 'unfair' advantage (i.e., experience of formal education constructs) that would see them perform disproportionately well. This study uncovered only anecdotal information to support this hypothesis, in the form of comments made by some university employees during the data collection stage of research. For example, the manager of one admission centre stated that in his experience it was matriculation students who had not gained sufficiently high marks in their leaving exams who used the STAT to 'artificially' inflate their university entrance score. There is a wide body of literature showing that prior formal academic experience is one of the best predictors of success in tertiary studies (Evans 2000, Somasundaram et al. 2006), but these do not assess success in alternative entrance exams. Research to date has produced inconclusive findings of comparative university performance of mature-age students and non-school leavers (Archer et al. 1999, Cantwell et al. 2001). Furthermore other factors may have affected the results, such as support in the form of tertiary enabling programs and pastoral care for 'disadvantaged' students. Consequently any justification for restricting applicants by age-on the basis of having an 'unfair' advantage in performance-appears at present anecdotal and empirically untested..$^{5}$

Some admission policies also restrict the use of the STAT to applicants who have no other means of grading. ${ }^{6}$ This means that applicants can only sit the STAT if they had not completed year 12 (i.e., matriculated) or a recognized vocational education training (VET) centre, studied at university, or achieved a recognized international equivalent of one of these. In this situation, the STAT is used primarily as an equity mechanism, rather than a mechanism for assessing generic input skills. Conversely, some university procedures/guidelines do allow the STAT in addition to other ranking mechanisms: invariably in these cases they allow the applicant to use the best possible ranking. This means that a low score in the STAT will not prejudice their application. What is significant to our focus is that the current disparate uses of the STAT reflect various institutional motivations for utilizing alternative admission tests. Some of these are specific to individual universities and their positioning in the tertiary market, or indeed even distinct interests and needs of departments and 
functions within particular institutions. The use of the STAT does not appear to contribute to either a unified university or sector-wide understanding of universities' role as accreditors of applicants' RPL in a holistic vision of lifelong learning.

As already mentioned, only two universities' policies unequivocally accept the STAT for admission into all their courses. The remainder provide qualifications of various sorts. In most cases, admission to certain courses is not allowed on the basis of STAT in most universities. Almost invariably, the restrictions apply to medical, law and engineering disciplines. An examination of the pre-requisite subjects, or prior learning, required for these courses suggests that the medical and engineering courses are structured heavily around specific competencies (e.g., calculus, human biology or physics). By contrast, no comparable specific competencies are cited for undergraduate law programmes for which use of the STAT is also barred. Here it would seem that the restriction of the STAT is justified on other (unpublished) criteria. On a practical level, these same courses are among the most prestigious and sought-after university programmes, where there is no shortage of 'traditional' applicants. In such cases, the admission of applicants using the STAT would have to be weighed against that of other applicants using readily quantifiable and comparable entrance data. With no financial incentive or external pressure to do otherwise, it appears that universities have avoided the contentious question of where such entrants would be ranked in an admission list by removing the possibility of entrance by this means.

Furthermore three other universities whose websites or admission-related paraphernalia claim universal acceptance of the STAT are found to contain contradictory information on a closer examination of their course materials. Direct contact with the universities confirmed that whilst the institutions have a broad philosophy of acceptance of the STAT, certain disciplines effectively 'quarantine' their courses from the institutional directive. Such inconsistent internal values about the contribution of the university to varied lifelong learning agendas are hardly surprising in organizations of such size and diverse interest groups (Brunsson 1989: 29). Moreover, such institutions exhibit contradictions that may also reflect institutional desires to support a role for the university as accreditor of generic input skills lifelong learning weakened by the influence of a external stakeholder-in this case a federal government which provides no financial incentive to encourage universities to enact these values in all processes and areas throughout the organization.

An analysis of the use of generic skills for admission to university programmes suggests much less uniformity within the tertiary sector about the place and extent of their contribution to the lifelong learning cycle as accreditors of skills developed elsewhere. In general, where the value of prior generic skills is recognized by institutions, these input skills are subject to a high degree of assessment. This runs counter to the argument the sector more consistently proposes for the generic skills that it develops in students, which are universally argued to be highly valuable but not able to be subjected to comparable assessment.

\section{Conclusion}

The conceptualization of universities' position within the lifelong learning cycles, in respect of the place and measurement of generic skills, presents both contradictions 
and concurrence within the sector. On the one hand, there are deep reservations about the purpose and suitability of submitting generic skills that institutions impart to their students to a standardized metric assessment. Widespread in the sector is the terminology of graduate attributes and a tendency to articulate abstract concepts, such as ethics and environmental awareness, more than objective skills like literacy and numeracy. University mission statements and learning theory texts have particularly highlighted the social and community, as well as economic, benefits of the lifelong learning they enable. The qualities of the sector's 'attributes' are generally much harder to isolate and measure than those skill sets that government has identified and proposed for assessment. Higher education has thus located itself as an important part of the lifelong learning agenda of recent years, on terms that support the current social presentation of universities and preserve the financial health of the entire sector.

On the other hand, recognition of the generic skills of those seeking admission to universities is rather more unevenly handled across the sector. How acceptable such skills are for admission is partially dependent on the positioning of individual institutions in the student market. Some universities have documentation that exhibits internal inconsistencies about acceptability of prior learning that reflect distinctions within disciplinary knowledge, course prestige, admission profiles and organizational sub-sections with responsibility for diverse institutional aims. Where concurrence can be seen across the sector in its view of generic input skills is in the degree to which they are expected to be rigorously assessed and quantified, with multiple qualifications made concerning their use for admission into universities. Here too, in the absence of a strong external demand to act otherwise, the sector has defined its contribution to this aspect of the lifelong learning cycle in narrow terms that do not jeopardize its claims to prestige and unique knowledge provision nor its economic well-being.

In general, such behaviour does not appear to represent deliberate duplicity on the part of sector or even institutions as a whole. The academy is managing environmental pressures, a range of organizational goals and institutionalized professional norms. At stake is a critical question that is being continually negotiated: how best should universities integrate lifelong learning? It forms an important part of the sector's sense of their social and community responsibilities, as well as a key business strategy for many institutions in an increasingly competitive market. Yet, at the same time, its acceptance must not undermine universities' status as providers of unique disciplinary expertise and a superior set of moral and ethical qualities and transferrable generic attributes in its graduates. With the change of federal government in 2007 and new public messages of value and support for higher education that are building confidence of increased funding for the sector, the next decade may prove crucial in enabling us to determine just how fundamental the recent articulation of lifelong learning engagement has been to the social mission, or simply to the financial exigencies, of the contemporary academy.

\section{Acknowledgement}

Support for this publication has been provided by the Australian Learning and Teaching Council (formerly the Carrick Institute for Learning and Teaching in Higher Education Ltd), an initiative of the Australian government Department of 
Education, Science and Training. The views expressed in this publication do not necessarily reflect the views of the ALTC.

The authors thank the anonymous referees for their constructive comments on earlier versions of this paper. However any opinions expressed or errors contained in this article are those of the authors alone.

\section{Notes}

1. In the US, the Council for Higher Education Accreditation was formed in 1996, with various earlier organizations preceding it for many years. In the UK the Quality Assurance Agency for Higher Education (QAA) was established in 1997 to provide an integrated quality assurance service for UK higher education. Again, it was preceded by other likeminded institutions. By contrast, in Australia the Australian Universities Quality Agency (AUQA) was only formed in 2001 and without the advantage of a foundation of prior attempts at external quality assurance. As Richard James (2003: 189) notes: 'the Australian higher education sector has had little sustained discussion and analysis of standards in recent years. As a result, very little is known about the relative standards and it is difficult to identify the processes by which standards are defined and monitored'.

2. One possible way of interpreting the issue would be through resource-based theory. Universities compete with each other for resources, students being one resource and legitimacy another.

3. The HEC was an arm of the then commonwealth-funded National Board of Employment, Education and Training (NBEET) which focused on higher education policy.

4. See http://www.australian-universities.com/groupings-of-australian-universities.php.

5. As part of this study the Australian Council for Education Research was contacted on 28 November 2007. They confirmed that they were not aware of any research-and had not conducted any of their own-as to why applicants should be restricted from sitting the STAT on age grounds, where the decision was based solely on empirically tested grounds of the comparative validity of test scores.

6. In most states and territories of Australia, university applicants are given a Tertiary Entrance Rank (TER) which is calculated by various means. The most common is a conversion of their Year 12 leaving exams. Other TERs are created formulaically by associating prior credentialed learning (such as TAFE or universities studies) into notional scores. Admission tests results such as the STAT, and overseas results, are also converted into a notional TER.

\section{References}

ACER (The Australian COUnCIL FOr EduCATIONAL ResEARCH) (2001) Graduate Skills Assessment: Summary report. Available online at: www.dest.gov.au/sectors/higher_education/ publications_resources/profiles/archives/graduate_skills_assessment_summary_report.htm (accessed 23 August 2007).

ACER (The Australian Council For Educational Research) (2002) Response to Issues Paper: Striving for quality: learning, teaching and scholarship Available online at: www.dest.gov.au/sectors/ higher_education/publications_resources/(accessed 23 August 2007).

Archer, J., Cantwell, R. and Bourke, S. (1999) Coping at university: An examination of achievement, motivation, self-regulation, confidence, and method of entry. Higher Education Research and Development, 18(1), 31-54.

ATN (Australian TECHNOLOGY NeTWORK) (2005) Response to the discussion paper: 'Learning and Teaching Performance Fund: future directions'. Available online at: http:/ /www.atn.edu.au (accessed 1 October 2007).

AVCC (Australian Vice Chancellors' Committee) (2006) Enhancing the Learning and Teaching Performance Fund: An AVCC proposal (Canberra: AVCC)

BARRIE, S. (2004) A research-based approach to generic graduate attributes policy. Higher Education Research and Development, 23(3), 261-275.

BILling, D. (2003) Generic cognitive abilities in higher education: An international analysis of skills sought by stakeholders. Compare: A Journal of Comparative Education, 33(3), 335-350.

BroomhaLL, S. (2004) Women's Medical Work in Early Modern France (Manchester: Manchester University Press).

Brunsson, N. (1985) The Irrational Organization: Irrationality as a basis for organizational action and change (New York: Wiley). 
BRUnSSON, N. (1989) The Organization of Hypocrisy: Talk, decisions, and actions in organizations (trans N. ADLER) (New York: Wiley).

Bucher, R. and Strauss, A. (1961) The professions in process. American Journal of Sociology, 66(4), 325-334.

Candy, P.C., Crebert, G. and O'LeARY, J. (1994) Developing Lifelong Learners through Undergraduate Education (Canberra: National Board of Employment, Education and Training).

CANTWELL, R., ARCHER, J. and BOURKe, S. (2001) A comparison of the academic experiences and achievement of university students entering by traditional and non-traditional means. Assessment and Evaluation in Higher Education, 26(3), 221-234.

Chanock, K., Clerehan, R., Moore, T. and Prince, A. (2004) Shaping university teaching towards measurement for accountability: Problems of the graduate skills assessment test. Australian Universities Review, 47(1), 22-29.

Chapman, J., Gaff, J., Toomey, R. and Aspin, D. (2005) Policy on lifelong learning in Australia. International Journal of Lifelong Education, 24(2), 99-102.

Clerehan, R., Chanock, K., MoOre, T. and Prince, A. (2003) A testing issue: Key skills assessment in Australia. Teaching in Higher Education, 8(2), 279-284.

CurTiS, D. and MCKenzIE, P. (2001) Employability Skills for Australian Industry: Literature review and framework development (Canberra: DEST/ACER).

EuRopeAn Ministers OF EDUCATION (1999) The Bologna Declaration of 19 June 1999. Available online at: www.bologna-berlin2003.de/pdf/bologna_declaration.pdf (accessed 3 March 2006).

Evans, M. (2000) Planning for the transition to tertiary study: A literature review. Journal of Institutional Research, 9(1). Available online at: www.air.org.au (accessed 7 December 2007).

FUNDING AND SUPPORT BRANCH, HighER EDUCATION GROUP (2006) Administrative Information for Providers: Student support (Canberra: Department of Education, Science and Training).

Golding, B., Marginson, S. and Pascoe, R. (1996) Changing Context, Moving Skills: Generic skills in the context of credit transfer and the recognition of prior learning (Canberra: Australian Government Publishing Service).

Gosden, R. and HAMPTON, G. (2001) Generic skills assessment: A new problem for tertiary students with learning disabilities. Australian Journal of Learning Disabilities, 6(1), 20-27.

GOW, L. and KEMBLER, D. (1990) Does higher education promote independent learning? HigherEducation, 19(3), 307-322.

Hambur, S., Rowe, K. and Luc, L. (2002) Graduate skills assessment: Stage one validity study. Australian Council for Educational Research. Available online at: http://www.dest.gov.au/sectors/ higher_education/publications_resources/other_publications/graduate_skills_assessment.htm (accessed 23 August 2007).

JAMES, R. (2003) Academic standards and the assessment of student learning: Some current issues in Australian higher education. Tertiary Education and Management, 9, 187-198.

JONGBLOED, B. (2002) Lifelong learning: Implications for institutions. Higher Education, 44(3/4), 413-431.

KNAPPER, C. (2001) Lifelong learning in the workplace. In A. M. RocHE and J. MCDONALD (Eds.) Systems, Settings, People: Workforce development challenges for the alcohol and other drugs field (Adelaide: National Centre for Education and Training on Addiction), pp. 129-137.

KnAPPER, C.K. and Cropley, A.J. (1991) Lifelong Learning and Higher Education (London: Kogan Page).

LEICHT, K.T. and FENNELl, M.L. (1997) The changing organizational context of professional work. Annual Review of Sociology, 23, 215-231.

LUCA, J. and Oliver, R. (2003) A framework to promote learning and generic skills. World Conference on Educational Multimedia, Hypermedia and Telecommunications (EDMEDIA) 2003, Honolulu, Hawaii, USA.

MAYER, E. (1992) Putting General Education to Work: The key competencies report. (Melbourne: Australian Education Council and Ministers for Vocational Education, Employment and Training).

MEYER, J. and ROWAN, B. (1991) Institutionalized organizations: Formal structure as myth and ceremony. In W. Powell and P. DiMaggio (Eds.) The New Institutionalism in Organizational Analysis (Chicago: The University of Chicago Press) pp. 41-62.

Michelson, J. (1996) 'Auctoritee' and 'experience': Feminist epistemology and the assessment of experiential learning. Feminist Studies, 22(3), 627-656.

MORRICE, L. (2007) Lifelong learning and the social integration of refugees in the UK: The significance of social capital. International Journal of Lifelong Education, 26(2), 155-172.

NBEET (NATIONAL BOARD OF EMPLOYMENT, EDUCATION AND TRAINING) (1990) Seminar on credit transfer, course length and nomenclature and postgraduate studies: Summary of proceedings (Canberra: Australian Government Printing Service).

Nelson, B. (2003) Doorstop transcript of the Hon. Brendan Nelson MP_Parliament House, Canberra 9/10/ 2003. Available online at: www.dest.gov.au/ministers/media/nelson/2003/10/n091003.asp (accessed 7 March 2006).

OECD (2003) Education policy analysis. Available online at: www.oecd.org (19 August 2006).

Schuetze, H. and Slowey, M. (2001) Participation and exclusion: A comparative analysis of nontraditional students and lifelong learners in higher education. Higher Education, 44(3/4), 309-327. 
Somasunduram, J., Bowser, D. and DAnAHER, P. (2006) Gate-keeping into the knowledge society: Have we got it right? Paper presented to the South East Asian Association for Institutional Research (SEAAIR), Langkawai, Malaysia.

Taylor, C., Peat, M. and Stewart, C. (2005) The student-staff partnership: Pooling our expertise to develop a user-friendly skills web site. Paper presented at the Higher Education Research and Development Society of Australia, Sydney, Australia.

TAYLOR, T. and Clemans, A. (2000) Avoiding the hoops: A study of recognition of prior learning processes in Australian faculties of education. Asia-Pacific Journal of Teacher Education, 28(3), 263-281.

Trowler, P. (1996) Angels in marble: Accrediting prior experiential learning in higher education. Studies in Higher Education, 21 (1), 17-31.

Watson, L. (2003) Lifelong learning in Australia. Available online at: www.canberra.edu.au/lifelong/ (accessed 12 July 2005).

WHEELAHAN, L. (2003) Recognition of prior learning and the problem of 'graduateness': The changing face of VET. The Sixth Australian VET research Association Conference, Australian Technology Park, Sydney, Australia. (9-11 April 2003).

Wheelahan, L., Dennis, N., Firth, J. Miller, P., Newton, D., Pascoe, S. and Veenker, P. (2003) Recognition of prior learning: Policy and practice in Australia. Report commissioned by the Australian Qualifications Framework Advisory Board. Available online at: http:/ /www.scu.edu.au/research/ rpl/ (accessed 5 February 2006).

Williams, C. (2005) The discursive construction of the 'competent' learner-worker: From key competencies to 'employability skills'. Studies in Continuing Education, 27(1), 33-49. 